\title{
PEMBELAJARAN MATERI JASA LINGKUNGAN
}

\author{
SRI MURNI SOENARNO \\ smurnis@yahoo.com \\ Program Studi Pendidikan Biologi, Fakultas Teknik, Matematika dan IPA \\ Universitas Indraprasta PGRI Jakarta
}

\begin{abstract}
Abstrak: Indonesia memiliki kekayaan alam yang berlimpah. Pemanfaatan sumber daya alam dengan cara-cara yang melampaui potensi pemulihan alami akan mempengaruhi ketersediaan jasa lingkungan dan dapat membahayakan kesejahteraan manusia di masa mendatang. Pemanfaatan jasa lingkungan adalah upaya pemanfaatan potensi jasa yang diberikan oleh fungsi ekosistem dengan tidak merusak dan tidak mengurangi fungsi pokok ekosistem tersebut. Untuk memenuhi kebutuhan hidup manusia tanpa merusak lingkungan di masa depan diperlukan pemahaman tentang jasa lingkungan oleh peserta didik sebagai generasi muda pembangun bangsa, oleh karena itu diperlukan pendidik yang paham tentang jasa lingkungan. Tulisan ini berdasarkan penelitian tentang pemahaman guru terhadap jasa lingkungan dan persepsi tentang pentingnya pembelajaran materi jasa lingkungan kepada siswa SMP. Mayoritas guru menganggap penting pembelajaran materi jasa lingkungan demi masa depan bangsa.
\end{abstract}

Kata kunci: jasa lingkungan, masa depan, pendidikan

Abstract: Indonesia has an abundance nature resource. Unwisely nature resources utilization through over-exploitation results in nature deterioration in Indonesia. Overexploitation affects the environmental service supplies and endangers human being in the future. Environmental services utilization is an effort to utilize the potential services of ecosystem functions without destroying and reducing the main functions. For the sake of guarantee sustainable life on the earth, it is required student understanding of environmental services; therefore it needed teachers who understand of environmental services. This article is based on the research about teacher understanding toward environmental services and perceptions about the importance of teaching environmental services material to junior high school student. Majority opinion of the teachers is important to educate environmental services for the future of nation.

Keywords: environmental services, future, education

\section{PENDAHULUAN}

Indonesia adalah negara yang memiliki kekayaan keanekaragaman hayati yang berlimpah. Berlimpahnya kekayaan alam ini dapat digunakan untuk menunjang kehidupan dan dapat mensejahterakan rakyatnya. Namun usaha pemanfaatan sumber daya alam Indonesia banyak yang menyebabkan kerusakan lingkungan. Penyebab kerusakan tersebut adalah karena sumber daya alam dieksploitasi dengan cara menguras atau ekstraksi berlebih (over-exploitation) seperti penebangan pepohonan tanpa penanaman kembali, penangkapan ikan berlebih, penangkapan hewan dan pengambilan tumbuhan langsung dari alam secara berlebih, dan penambangan yang abaikan kelestarian lingkungan. Pemanfaatan tersebut hanya menguntungkan dalam jangka waktu pendek, selanjutnya yang muncul adalah kerugian berupa kerusakan lingkungan yang harus dibayar dengan harga mahal. Oleh karena itu perlu pemanfaatan sumber daya alam yang bijak, yaitu yang tidak merusak lingkungan dan sumber daya alam. 
Dalam sumber daya alam selain terkandung nilai ekonomi yang tampak (tangible), terdapat nilai ekonomi yang tidak tampak (intangible). Nilai ekonomi yang tidak tampak tersebut terkandung dalam jasa lingkungan. Jasa lingkungan berarti memanfaatkan potensi lingkungan tanpa harus dengan cara yang merusak lingkungan itu sendiri dan tidak mengurangi fungsi utamanya. Untuk itu diperlukan sumber daya manusia sebagai pengelola dan pemanfaat sumber daya alam yang mampu memasukkan prinsip kelestarian alam dan lingkungan dalam usaha-usaha pemanfaatan sumber daya alam dan lingkungan. Hal itu berarti upaya meningkatkan kesejahteraan hidup manusia dengan tetap menjaga kelestarian alam demi memenuhi kebutuhan hidup generasi saat ini dan generasi yang akan datang.

Berdasarkan uraian di atas, maka penelitian ini dilakukan dengan tujuan memperoleh gambaran mengenai pengetahuan guru tentang jasa lingkungan, dengan cara menggali informasi dan data mengenai pengetahuan, serta pendapat mereka mengenai jasa lingkungan.

\section{TINJAUAN PUSTAKA}

Sumber daya alam menyediakan dua komoditas yang dapat dimanfaatkan oleh manusia, yaitu:

1. Berbentuk barang (goods) yang merupakan ekstraksi dari alam, seperti biota darat (contohnya kayu, rotan, tumbuhan herbal, dll), biota akuatik (contohnya berbagai jenis ikan, rumput laut, dll) dan berbagai bahan tambang (contohnya minyak bumi, emas, timah, dll).

2. Berbentuk jasa (services), yang disebut dengan jasa lingkungan, yaitu sesuatu yang bukan berbentuk material, merupakan keuntungan yang diperoleh dari alam non ekstraksi, seperti hidrologi, keindahan landskap, kesejukan (penghasil $\mathrm{O}_{2}$ dan penyerap karbon), dan lain-lain.

Selama ini komoditas dalam bentuk baranglah yang banyak dimanfaatkan, sedangkan komoditas dalam bentuk jasa kurang diperhatikan. Menurut RUPES (2009: 2), definisi jasa lingkungan adalah penyediaan, pengaturan, penyokong proses alami, dan pelestarian nilai budaya oleh suksesi alamiah dan manusia yang bermanfaat bagi keberlangsungan kehidupan. Jadi dengan demikian, pemanfaatan jasa lingkungan adalah suatu upaya pemanfaatan potensi jasa (baik berupa jasa penyediaan, jasa pengaturan, jasa budaya, maupun jasa pendukung) yang diberikan oleh fungsi ekosistem dengan cara tidak merusak dan tidak mengurangi fungsi pokok ekosistem tersebut.

Jasa lingkungan adalah produk sumber daya alam hayati dan ekosistemnya yang berupa manfaat langsung (tangible) dan/atau manfaat tidak langsung (intangible). Contoh-contoh jasa lingkungan adalah jasa wisata alam, jasa perlindungan tata air (hidrologi), kesuburan tanah, pengendalian erosi dan banjir, keindahan dan keunikan alam, penyerapan dan penyimpanan karbon (carbon offset). Selain itu, jasa lingkungan dihasilkan dari berbagai jenis penggunaan lahan (hutan atau pertanian), juga perairan baik air tawar (sungai, danau, rawa) maupun laut.

Manusia sudah ada yang memanfaatkan jasa lingkungan secara tidak langsung, sehingga jarang memperhitungkannya secara ekonomi. Namun apabila terjadi bencana alam seperti banjir, longsor, kekeringan, manusia baru sadar adanya jasa lingkungan yang sering diabaikan. Merskipun demikian penghitungan ekonomi (valuasi lingkungan) hanya dilihat dari sudut kerugian material akibat bencana alam, jarang diperhitungkan dari jasa lingkungan yang sebelumnya telah hilang akibat ulah manusia sehingga mengakibatkan timbulnya bencana alam antropogenik. 
Pemanfaatan sumber daya alam dengan cara-cara yang melampaui potensi pemulihan alami akan mempengaruhi ketersediaan jasa lingkungan di masa mendatang. Jika terus berlanjut, keberadaan aset lingkungan akan menurun tajam dan jasa lingkungan yang saat ini diperoleh cuma-cuma akan hilang atau menjadi mahal. Pada akhirnya, hal tersebut akan membahayakan kesejahteraan manusia (RUPES, 2009: 3). Oleh karena itu, untuk menunjang kehidupan dan meningkatkan kesejahteraan hidup manusia, pemanfaatan jasa lingkungan perlu lebih ditingkatkan agar seimbang dengan pemanfaatan dari ekstraksi alam, demi menjamin masa depan manusia.

Salah satu kawasan hutan yang penting adalah hutan lindung. Menurut definisinya, hutan lindung adalah kawasan hutan yang mempunyai fungsi pokok sebagai perlindungan sistem penyangga kehidupan untuk mengatur tata air, mencegah banjir, pengendalian erosi, mencegah intrusi air laut, dan memelihara kesuburan tanah (Permenhut No. P.22/Menhut-II/2012). Dari definisi ini, tampak bahwa potensi yang dikandung oleh hutan lindung sedemikian besar, tetapi selama ini hutan lindung adalah termasuk kawasan yang diabaikan, karena tidak diperbolehkan sembarangan dimanfaatkan mengingat fungsi pentingnya adalah sebagai perlindungan sistem penyangga kehidupan.

Melihat potensi jasa lingkungan untuk menunjang kelangsungan hidup manusia, maka Pemerintah Indonesia melalui Kementerian Kehutanan mengeluarkan Peraturan Menteri Kehutanan (Permenhut) No. P.22/Menhut-II/2012 tentang Pedoman Kegiatan Usaha Pemanfaatan Jasa Lingkungan Wisata Alam Pada Hutan Lindung. Hutan lindung adalah kawasan yang terbatas, namun memiliki banyak potensi yang akan menjadi mubazir jika tidak dimanfaatkan secara optimal. Dengan usaha pemanfaatan jasa lingkungan dimungkinkan pemanfaatan hutan lindung yang selama ini diabaikan untuk menambah pendapatan negara dan mensejahterakan rakyat khususnya yang berdomisili di sekitar hutan lindung. Dengan memanfaatkan jasa lingkungan banyak keuntungan yang diperoleh tanpa merusak lingkungan dan tidak mengurangi fungsi utamanya. Apabila pemanfaatan hutan lindung dapat dimanfaatkan melalui jasa lingkungan dengan wisata alam, sebagai satu contoh, maka akan semakin banyak kawasan terbatas yang dapat dikembangkan melalui jasa lingkungan.

Pemanfaatan kekayaan sumber daya alam Indonesia harus berlangsung secara berkelanjutan, yaitu untuk memenuhi kebutuhan hidup generasi saat kini tanpa mengganggu kemampuan alam untuk memenuhi kebutuhan generasi yang akan datang. Jasa lingkungan dihasilkan dari perpaduan aset alami, kualitas sumber daya manusia, dan teknologi pengelolaan. Untuk itu, diperlukan sumber daya manusia yang memiliki kemampuan ilmu dan keterampilan serta bijak dalam mengelola sumber daya alam tanpa merusak. Pengembangan sumber daya manusia tersebut dilaksanakan melalui pendidikan yang sebagaimana tercantum dalam Pasal 3 UU No. 20 Tahun 2003 tentang Sistem Pendidikan Nasional yang menyatakan bahwa pendidikan nasional berfungsi mengembangkan kemampuan dan membentuk watak serta peradaban bangsa yang bermartabat dalam rangka mencerdaskan kehidupan bangsa, bertujuan untuk berkembangnya potensi peserta didik agar menjadi manusia yang beriman dan bertakwa kepada Tuhan Yang Maha Esa, berakhlak mulia, sehat, berilmu, cakap, kreatif, mandiri, dan menjadi warga negara yang demokratis serta bertanggung jawab.

Menurut Irianto (2013: 190), pendidikan adalah untuk masa depan anak. Masa depan anak akan terbentuk seiring dengan perkembangan zaman. Setiap anak akan menuju masa depan dengan kemampuan masing-masing. Siapa yang dapat memanfaatkan kesempatan dengan berpijak pada kemampuannya adalah yang memungkinkan dapat mencapai kesuksesan. Selanjutnya menurut Faturrahman dkk (2012: 163), tugas guru adalah mengarahkan dan membimbing peserta didik agar semakin terbina dan berkembang potensinya, selain itu guru mampu mengilhami peserta didiknya dan mampu 
mendorongnya untuk mengemukakan gagasan-gagasannya. Jadi dengan demikian, pembelajaran tentang jasa lingkungan akan menambah pengetahuan dan peluang peserta didik hingga mereka kelak menjadi manusia yang kreatif, memiliki kemampuan dan mandiri dalam mengelola potensi sumber daya alam Indonesia dengan cara tidak merusak.

Untuk mengusahakan pemanfaatan jasa lingkungan diperlukan sumber daya manusia yang kreatif, berilmu dan paham akan konsep-konsep jasa lingkungan yang ramah lingkungan. Oleh karena itu, diperlukan pemahaman tentang jasa lingkungan sejak usia muda, sehingga pada saat seseorang mencapai kedewasaannya ia mampu mengembangkan usaha jasa lingkungan ini, bukan saja untuk pemenuhan kebutuhan dirinya sendiri, tetapi juga untuk bangsa dan negara sebagai bagian dari tanggung jawabnya sebagai warga negara Republik Indonesia.

Berdasarkan penelitian Widoyoko dan Rinawati (2012: 288), besarnya pengaruh dari masing-masing aspek kinerja guru terhadap motivasi belajar siswa secara berurutan adalah: penguasaan materi pembelajaran, kemampuan mengelola pembelajaran, penguasaan strategi pembelajaran, pemahaman terhadap karakteristik siswa, dan penguasaan penilaian hasil belajar siswa. Hasil penelitian tersebut menunjukkan bahwa penguasaan materi pembelajaran akan mempengaruhi motivasi belajar siswa. Oleh karena itu, guru diharapkan dapat menguasai materi pembelajaran sehingga dapat menarik perhatian peserta didik dan memotivasinya agar mengembangkan potensi dirinya.

\section{METODE}

Penelitian ini merupakan penelitian deskriptif yang menggali pemahaman guru tingkat sekolah menengah pertama (SMP) tentang jasa lingkungan dan persepsi pentingnya pembelajaran materi jasa lingkungan kepada peserta didiknya. Subyek penelitian adalah 35 guru peserta Pendidikan dan Pelatihan (Diklat) Konservasi Alam. Metode pengumpulan data dengan wawancara mendalam. Instrumen yang digunakan adalah pedoman wawancara. Pertanyaan diajukan sebelum dan sesudah penyajian materi. Data yang diperoleh diolah secara kualitatif dan kuantitatif. Hasil analisis dipaparkan secara deskriptif dan dalam bentuk tabel.

\section{HASIL DAN PEMBAHASAN}

Pada tahap awal, kepada guru diajukan pertanyaan pertama tentang pernah atau tidaknya mereka mendengar istilah dan konsep jasa lingkungan, pertanyaan ini diajukan sebelum penyajian materi. Hasil yang diperoleh adalah mayoritas, yaitu 31 orang $(88,57 \%)$, mereka belum pernah mendengar istilah tersebut. Hasil dari pertanyaan pertama dipaparkan pada Tabel 1.

Tabel 1. Guru yang pernah/tidak mendengar istilah jasa lingkungan

\begin{tabular}{ccc}
\hline Pernah mendengar & Belum pernah & Total jumlah \\
\hline 4 & 31 & 35 \\
$11,43 \%$ & $88,57 \%$ & $100 \%$ \\
\hline
\end{tabular}

Guru-guru yang belum pernah mendengar istilah jasa lingkungan ini bahkan kemudian menanyakan kepada peneliti, apa arti istilah tersebut dan nilai penting dari pemanfaatan jasa lingkungan tersebut.

Tahap selanjutnya adalah mewawancarai lebih mendalam empat guru $(11,43 \%)$ yang pernah mendengar istilah tersebut. Dari keempat guru tersebut, meskipun pernah mendengar ternyata tidak sepenuhnya paham dengan konsep jasa lingkungan. Menurut mereka, penjelasan-penjelasan tentang jasa lingkungan tidak terlalu banyak dan jelas, 
sehingga membuat mereka tidak paham dengan konsep tersebut. Ketidakpahaman tersebut membuat mereka tidak menganggap penting jasa lingkungan.

Setelah penyajian materi tentang jasa lingkungan, guru-guru tesebut kemudian diwawancarai tentang pendapat mereka tentang pentingnya materi tersebut dan keinginan mereka untuk mengajarkan materi jasa lingkungan kepada peserta didik mereka. Dengan penjelasan materi jasa lingkungan yang dilanjutkan dengan tanya jawab antara narasumber dan guru-guru tersebut rupanya memberikan hasil yang positif, yaitu munculnya pemahaman baru tentang jasa lingkungan. Saat diwawancarai, mayoritas mereka menganggap pembelajaran jasa lingkungan penting dan bersedia untuk mengajarkannya kepada peserta didik mereka. Hasil dipaparkan pada Tabel 2.

Tabel 2. Penilaian penting dan keinginan mengajarkan materi jasa lingkungan oleh guru

\begin{tabular}{cccc}
\hline Penting diajarkan & Ragu-ragu & Tidak penting & Total jumlah \\
\hline 24 & 8 & 3 & 35 \\
$68,57 \%$ & $22,86 \%$ & $8,57 \%$ & $100 \%$ \\
\hline
\end{tabular}

Guru yang menganggap materi tersebut penting untuk diajarkan berjumlah 24 orang $(68,57 \%)$. Alasan yang diberikan adalah karena materi tersebut dapat berguna bagi peserta didik dan menjadi salah satu alternatif persiapan menghadapi masa depannya. Apabila guru tersebut menganggap penting materi jasa lingkungan untuk diajarkan kepada peserta didiknya, dia akan termotivasi untuk menguasai materi dan mengembangkan strategi pembelajaran agar dapat menarik perhatian peserta didik sehingga mereka menjadi paham dan sadar akan pentingnya jasa lingkungan untuk masa depan mereka sendiri.

Guru yang menganggap tidak penting materi tersebut diajarkan berjumlah tiga orang $(8,57 \%)$. Alasan yang dikemukakan adalah karena materi yang sudah ada saat ini sudah mencukupi untuk peserta didik, sehingga tidak perlu ditambah lagi. Guru yang menyatakan ragu-ragu berjumlah delapan orang $(22,86 \%)$. Alasan yang dikemukakannya tidak jauh berbeda atau mirip dengan alasan dari guru yang menyatakan tidak penting, yaitu karena materi saat itu sudah cukup banyak, kalau ada penambahan materi jasa lingkungan, mereka ragu-ragu apakah materi tersebut sempat akan diajarkan.

Leksono dkk (2013: 417) menyatakan bahwa bagaimana mengemas konten untuk dapat diajarkan ke siswa juga perlu dilatih, hal ini diharapkan siswa yang diajar akan mampu menghargai dan peduli terhadap lingkungan. Pendapat Leksono dkk (2013) ini dapat mengatasi keragu-raguan guru tentang penambahan materi jasa lingkungan. Dengan kata lain, pengemasan materi jasa lingkungan ke dalam materi-materi lainnya dapat dengan cara mengintegrasikan pengetahuan baru tersebut ke dalam pengetahuan yang sudah ada. Disamping itu penguasaan materi jasa lingkungan dapat meningkatkan motivasi belajar peserta didik, sebagaimana telah diutarakan oleh Widoyoko dan Rinawati (2012: 288). Tidak hanya pengemasan saja yang perlu dilatihkan kepada guru, tetapi juga pendalaman materi sehingga guru memiliki kepercayaan diri yang tinggi saat mengajarkan materi jasa lingkungan tersebut. Untuk pembelajaran jasa lingkungan ini diperlukan kemampuan yang dapat menarik perhatian peserta didik sehingga tidak hanya pengetahuan atau kemampuan kognitif yang dikuasai peserta didik, tetapi juga memberikan pengaruh afektif berupa sikap yang mendukung pemanfaatan jasa lingkungan yang berarti membentuk individu yang pro-konservasi.

Materi jasa lingkungan tidak perlu diajarkan secara terpisah dalam pokok bahasan tersendiri. Materi ini merupakan materi yang dapat disisipkan di berbagai mata pelajaran yang ada. Dalam Biologi, memang sudah jelas materi ini dapat disisipkan di berbagai pokok bahasan, seperti yang terkait ekologi, daur zat hara untuk tumbuhan, fotosintesis, 
dan banyak lagi. Jasa lingkungan juga dapat dikaitkan dengan pelajaran Agama, khususnya yang terkait dengan penciptaan alam, bahwa Tuhan memberikan banyak potensi untuk menunjang kehidupan manusia. Mata pelajaran Ekonomi pun dapat membahas jasa lingkungan khususnya dalam penghitungan nilai ekonomi yang tidak tampak (intangible), yang masih sering diabaikan. Dengan demikian, materi jasa lingkungan ini dapat menjadi pengetahuan tambahan bagi peserta didik bahwa banyak potensi di sekitar manusia yang belum digarap untuk dapat menunjang kehidupannya, dan bahwa pemanfaatan sumber daya alam itu tidak harus dengan cara yang merusak, sehingga pemanfaatannya dapat lebih berkelanjutan.

Materi jasa lingkungan adalah materi yang bersifat interdisipliner, yaitu materi yang dapat diajarkan pada berbagai mata pelajaran. Materi yang terkait masalah lingkungan adalah materi yang melibatkan banyak bidang ilmu pengetahuan, tidak dimonopoli oleh Biologi saja. Baik ilmu-ilmu pengetahuan alam (IPA) dan ilmu-ilmu pengetahuan sosial (IPS) sama besar pengaruh dalam masalah lingkungan, karena penyebab timbulnya masalah-masalah lingkungan adalah manusia, jadi sifatnya adalah antropogenik. Manusia yang menyebabkan timbulnya masalah, manusia pula yang harus mencari pemecahan masalah yang ditimbulkannya. Contohnya banjir di wilayah hilir disebabkan oleh terbukanya lahan di daerah hulu, oleh karena itu perlu penanaman kembali pepohonan dan upaya konservasi tanah di wilayah hulu agar air permukaan (run-off) dapat segera diserap oleh tanah untuk menghindari banjir. Oleh karena itu, penyelesaian masalah lingkungan harus secara holistik atau menyeluruh dan interdisipliner yang melibatkan berbagai bidang ilmu pengetahuan, agar masalah terselesaikan secara tuntas.

Peserta didik diajarkan sejak dini untuk mengenali masalah-masalah lingkungan dan belajar untuk mencari alternatif pemecahan masalah melalui berbagai bidang ilmu pengetahuan. Dengan demikian, mereka lebih terbuka wawasannya dan menjadi kreatif dalam mencari pemecahan masalah-masalah yang dihadapinya serta menambah peluang usaha untuk menopang kehidupan dan meningkatkan kesejahteraannya. Apabila hal tersebut tercapai, berarti tujuan pendidikan nasional yang diamanatkan dalam Pasal 3 UU No. 20 tahun 2003 tentang Sistem Pendidikan Nasonal telah tercapai.

\section{PENUTUP}

\section{Simpulan}

Dari uraian di atas dapat disimpulkan bahwa:

1. Kurangnya sosialisasi mengenai jasa lingkungan kepada masyarakat umum, sehingga banyak masyarakat yang tidak paham dan tidak menganggap penting konsep tersebut.

2. Pembelajaran materi jasa lingkungan kepada peserta didik merupakan bentuk antisipasi yang bertujuan agar generasi muda lebih siap dalam menghadapi masa depannya.

3. Jasa lingkungan merupakan suatu alternatif peluang untuk pemanfaatan ekosistemekosistem alami tanpa merusak potensi serta fungsinya, namun dapat mendatangkan pendapatan negara serta mensejahterakan masyarakat di sekitar ekosistem tersebut.

4. Pemanfaatan jasa lingkungan membutuhkan pengembangan sumber daya manusia yang berilmu, kreatif dan mampu menerapkan konsep jasa lingkungan dalam teknologi yang dikembangkannya.

\section{Saran}

Mengingat kerusakan lingkungan di Indonesia masih terus terjadi, di lain pihak tingkat kesejahteraan masyarakat harus meningkat, maka usaha-usaha pemanfaatan jasa lingkungan perlu digalakkan. Untuk menjaga keberlanjutan upaya tersebut, maka 
pembelajaran materi jasa lingkungan perlu dilaksanakan sesegera mungkin, agar generasi muda memiliki modal pengetahuan dan keterampilan serta mengembangkan kreativitas terkait pemanfaatan jasa lingkungan.

\section{DAFTAR PUSTAKA}

Faturrahman, I.K. Ahmadi, S. Amri, H.A. Setyono. 2012. Pengantar Pendidikan. Jakarta: PT. Prestasi Pustakaraya.

Irianto, A. 2013. Pendidikan Sebagai Investasi Dalam Pembangunan Suatu Bangsa. Jakarta: Kencana - Prenada Media Group.

Leksono, S.M., N. Rustaman, S. Redjeki. 2013. Kemampuan profesional guru biologi dalam memahami dan merancang model pembelajaran konservasi biodiversitas di SMA. Cakrawala Pendidikan, 32(3), 408-419.

RUPES (Rewards For Use Of And Shared Investment In Pro-Poor Environmental Service). 2009. Gagas Kebijakan Konsep Jasa Lingkungan dan Pembayaran Jasa Lingkungan di Indonesia. Bogor: RUPES World Agroforestry Center ICRAF Southeast Asia Regional Office.

Peraturan Menteri Kehutanan Republik Indonesia No. P.22/Menhut-II/2012 tentang Pedoman Kegiatan Usaha Pemanfaatan Jasa Lingkungan Wisata Alam Pada Hutan Lindung.

Undang-undang Republik Indonesia No. 20 Tahun 2003 tentang Sistem Pendidikan Nasional.

Widoyoko, S.E.P., A. Rinawati. 2012. Pengaruh kinerja guru terhadap motivasi belajar siswa. Cakrawala Pendidikan, 31(2), 278-289. 